\title{
Lion (Panthera leo) ecology and survival in protected areas of Ethiopia
}

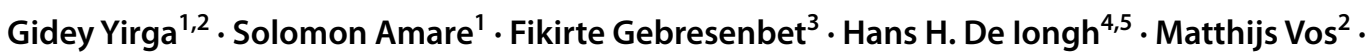 \\ Claudio Sillero-Zubiri ${ }^{6,7} \cdot$ Hans Bauer ${ }^{4,6}$
}

Received: 13 December 2019 / Accepted: 29 May 2021 / Published online: 14 September 2021

(C) The Author(s) 2021

\begin{abstract}
Ethiopia is renowned for its cultural and biological diversity and covers an important share of lion habitat in Africa, providing connectivity between East and Central Africa. The aim of this study was to investigate the status of lions and human-lion conflict in several protected areas of Ethiopia and to present an overview on lion distribution nationally. We used call-ups and semi-structured interviews with 809 randomly selected pastoralists to investigate human-lion conflict and pastoralist perceptions towards lions in five priority sites and collected further anecdotal information for all other known or possible lion range. We had chance encounters with six lions, but we observed no lion responses to the call-ups. We recorded 145 spotted hyaena and 23 jackal responses at, respectively, 25 and 13 of the 46 call-up stations. Overall, respondents viewed lions as dangerous carnivores, but nonetheless responded that lions should be present regionally, preferably in restricted areas. Most respondents disagreed that the killing of lions should be allowed, but we note that a small minority strongly agreed to killing. A large majority of respondents agreed that more people need to be given information about lions. Respondents mentioned spotted hyaena and leopard as the main predators on all livestock followed by jackal (shoats) and lion (mainly cattle). The impact of depredation on livestock mortality was nearly twice that of disease. Our results strongly suggest that lion densities are low and may have substantially decreased in Awash, Nechisar, Chebera-Churchura, and Mago National Parks and in Kaffa Biosphere Reserve due to conflict, habitat loss and especially ineffective protection. Anecdotal information suggests that lions are widespread but rare and that there is no stronghold in Ethiopia. Considering the unique evolutionary background of Ethiopia as the bridge between Central and East African lion populations, and the significant role of the lion in Ethiopian history and culture, we argue that more emphasis should be given to the protection of prioritized lion populations.
\end{abstract}

Keywords Conflict $\cdot$ Conservation $\cdot$ Ethiopia $\cdot$ Lion $\cdot$ Perception

\section{Introduction}

Africa supports iconic mammalian biodiversity (Western 2003), and the lion is emblematic as keystone and umbrella species (Bauer et al. 2015a). Large carnivores such as lions
(Panthera leo), cheetahs (Acinonyx jubatus) and African wild dogs (Lycaon pictus) have significantly declined in their geographic range and population sizes (Ray et al. 2005; Schuette et al. 2013; Bauer et al. 2015a; Durant et al. 2017). Lions are important in keeping the ecological structure and
Handling Editor: Carlos Fonseca.

Hans Bauer

hans.bauer@zoo.ox.ac.uk

1 Department of Biology, Mekelle University, P.O. Box 231, Mekelle, Ethiopia

2 Ruhr University Bochum, Faculty of Biology and Biotechnology, Theoretical and Applied Biodiversity Research, Universitätsstraße 150, 44780 Bochum, Germany

3 Department of Biology, Luther College, 700 College Dr, Decorah, IA, USA
4 Evolutionary Ecology Group, University of Antwerp, Groenenborgerlaan 171, 2020 Antwerp, Belgium

5 Institute of Environmental Sciences, Leiden University, POB 9518, 2300 RA Leiden, The Netherlands

6 Wildlife Conservation Research Unit, Zoology, University of Oxford, Recanati-Kaplan Centre, Tubney House, Tubney OX13 5QL, UK

7 The Born Free Foundation, 14 Carfax, Horsham RH12 1ER, UK 
balance of terrestrial communities (Sinclair 2003) and play an important role in human culture (Patterson 2007; Gebresenbet et al. 2017). Classified as Vulnerable on the IUCN Red List of Threatened species, the lion's range is now $8 \%$ of its historical range (Bauer et al. 2015b). The leading causes of their continent-wide decline are killing (often related to conflict), habitat loss, prey base depletion and trade (Bauer et al. 2015b; Riggio et al. 2013).

Ethiopia is renowned for its cultural and biological diversity; it has an extensive extant lion range providing connectivity between East and Central Africa (EWCA 2012). This has genetic implications as well since Ethiopia has been identified as an admixture zone between the northern and southern subspecies of lions (Bertola et al. 2016). The lion is considered a national symbol and an important element of the national identity, as seen in its representation on coins, stamps and on the old national flag (EWCA 2012). However, Ethiopia's lions are under increased pressure and are declining rapidly due to conflict with humans and habitat loss (Gebresenbet et al. 2009). Traditional lion hunting for prestige and as a rite of passage also persists in places like Awash and Mago National Parks (NP) among the Mursi, Hamar, Tsemai and Ari ethnic groups.

The present study was conducted to assess lion populations in several protected areas of Ethiopia, namely Awash, Nechisar, Chebera-Churchura and Mago NP and Kaffa
Biosphere Reserve. We also collected information on conflict reports and pastoralist perceptions around these protected areas, in order to determine the extent of human-lion conflict. We present our findings along with expert information on the other lion populations across Ethiopia. We suggest that this information is crucially important for the conservation of lions and for a better understanding of the potential actions local authorities and local people may take to prevent and mitigate human-carnivore conflict.

\section{Study areas}

This study was conducted in five protected areas in Ethiopia (Fig. 1). Although we found no published information, historical presence of viable lion populations in each of these areas is documented.

Awash NP covers $756 \mathrm{~km}^{2}$ and is centred on $9^{\circ} 00^{\prime}$ $\mathrm{N} / 40^{\circ} 00^{\prime} \mathrm{E}$; it is the oldest legally gazetted national park in Ethiopia (Alemayehu 2011). Altitude ranges between 750 and 1916 m.a.s.l. (Ebro et al. 2004). There are 86 mammal species in total (Tilahun et al. 1996), larger mammals include lion, spotted hyaena (Crocuta crocuta), striped hyaena (Hyaena hyaena), leopard (Panthera pardus), golden jackal (Canis aureus), bat eared fox (Otocyon megalotis), beisa oryx (Oryx beisa), soemmerring's gazelle (Nanger
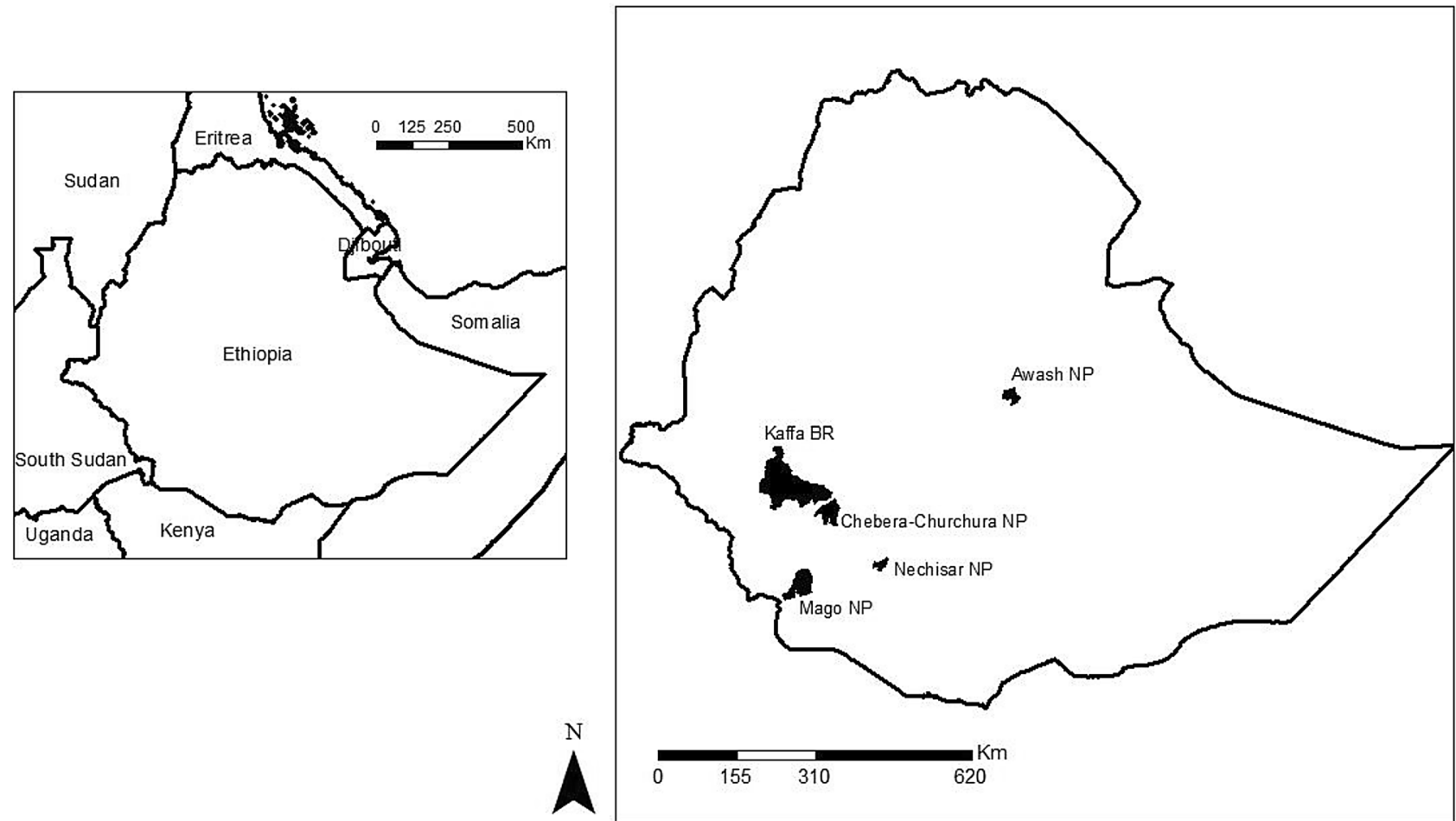

Fig. 1 Map of Ethiopia showing the location of Awash, Nechisar, Chebera-Churchura and Mago National Parks and Kaffa Biosphere Reserve in Ethiopia 
soemmerringii), lesser kudu (Tragelaphus imberbis), greater kudu (Tragelaphus strepsiceros), waterbuck (Kobus ellipsiprymnus), Salt's dik-dik (Madoqua saltiana), Abyssinian hare (Lepus abessinicus), common warthog (Phacochoerus africanus) olive baboon (Papio anubis) and hamadryas baboon (Papio hamadryas).

Nechisar NP, covering $436 \mathrm{~km}^{2}$ of land and $78 \mathrm{~km}^{2}$ of water (Hillman 1993) is centred on $5^{\circ} 80^{\prime} \mathrm{N} / 37^{\circ} 40^{\prime}$ $\mathrm{E}$ (Shimelse et al. 2010). Altitude ranges between 1108 and 1650 m.a.s.l. There are 84 species of mammals in total, larger mammals include the endemic Swayne's hartebeest (Alceluphus buselaphus spp. swaynei), plains zebra (Equus quagga), Grant's gazelle (Nanger granti), Guenther's dik-dik (Madoqua guentheri), Greater kudu, lion and spotted hyaena (Shibru 2016; Hillman 1993).

Chebera-Churchura NP, covering $1250 \mathrm{~km}^{2}$ is centred on $6^{\circ} 90 \mathrm{~N} / 36^{\circ} 50^{\prime} \mathrm{E}$ (Timer 2005). Altitude ranges from 550 to 1700 m.a.s.l. (Timer 2005). The park hosts a total of 37 larger mammalian species that include elephant (Loxodonta africana), African buffalo (Syncerus caffer), hippopotamus (Hippopotamus amphibious), leopard, lion, spotted hyaena, wild dog and three species of primates (Timer 2005).

Mago NP, covering $2162 \mathrm{~km}^{2}$ is located around $5^{\circ}$ $40 \mathrm{~N} / 36^{\circ} 15^{\prime} \mathrm{E}$, with nearly $220 \mathrm{~km}^{2}$ set aside for sugar plantation and community conservation. Altitude ranges from 400 to 2520 m.a.s.l. The park hosts 81 species of larger mammals that include elephant, spotted hyaena, leopard, cheetah (Acinonyx jubatus), golden jackal, lion, buffalo, waterbuck, bushbuck, greater kudu, lesser kudu, duiker, tiang (Damaliscus lunatus), oryx, common baboon, vervet monkey (Chlorocebus pygerythrus), lelwel hartebeest (Alcelaphus buselaphus lelwel), grant's gazelle, gerenuk (Litocranius walleri), giraffe (Giraffa camelopardalis) and gereza (Colobus guereza).

Kaffa Biosphere Reserve covering $7601 \mathrm{~km}^{2}$ is located around $7^{\circ} 30^{\prime} \mathrm{N} / 36^{\circ} 00^{\prime} \mathrm{E}$. Altitude ranges from 500 to 3350 m.a.s.l.; lions occur only in the eastern, higher parts (Gebresenbet et al. 2017). Kaffa is Ethiopia's first biosphere reserve and apart from its importance for conservation of unique biodiversity, is the origin of wild coffee (NABU International Foundation for Nature 2012).

\section{Methods}

\section{Field surveys}

Some large carnivore research methods require roads, either as a substrate (spoor counts, Bauer et al. 2014) or to provide access to a large number of grid cells to do call-ups or individual recognition (Gilfillan et al. 2016) across a representative study area. In the absence of roads, foot transects and camera traps can be used, but at our scale that would take resources far beyond our capacity. Despite poor road access, we decided to use call-ups opportunistically at all locations accessible by road within or on the boundaries of our study sites; our interpretation will take this imperfect design into account. Call-ups were performed in each area following a protocol adapted from Ogutu and Dublin (1998) in September 2014 through April 2015. A total of 46 call-ups were performed (Table 1). Buffalo calf distress call, gnu-hyaena distress and pig sounds were played at full volume on an MP3 player connected to a megaphone (TM-45 45 W Megaphone, Monacor, United Kingdom) mounted onto the roof of a vehicle. We rotated the speaker $90^{\circ}$ after 5 min broadcast to provide $360^{\circ}$ coverage and in each call-up we stayed for a total period of $60 \mathrm{~min}$, two cycles of $20 \mathrm{~min}$ broadcast and 10 min silence. During the 10-min silence, we scanned the entire area for eye reflection using a spotlight with a red filter followed by powerful torches (Maglite ML100 LED, MAGLITE, USA). Responding predators were identified and counted. We assumed a response distance of $2 \mathrm{~km}$ (Bauer and De Iongh 2005). Call-up stations were located on all roads in open areas to have relatively good visibility and were at least $5 \mathrm{~km}$ apart. For safety of local pastoralists, call-up stations were located at least $2.5 \mathrm{~km}$ from settlement boundaries. Accessibility of NPs in Ethiopia is poor; in total there were only 46 call-up locations that met the criteria above, many of them actually on park boundaries. We recorded animals
Table 1 Number of spotted hyaena, jackal, leopard and buffalo that responded and animals found along road transect between call-up stations in Awash, Nechisar, CheberaChurchura and Mago National Parks and in Kaffa Biosphere Reserve, Ethiopia

\begin{tabular}{lclllll}
\hline National Parks & Call-ups & \multicolumn{2}{l}{$\begin{array}{l}\text { Responding animals: total (mean per } \\
\text { call-up) }\end{array}$} & Road encounters \\
\cline { 2 - 6 } & & Hyena & Jackal & Leopard & Buffalo & \\
\hline Awash & 15 & $78(5.2)$ & $16(1)$ & $2(0.001)$ & 0 & 1 striped hyena, 1 serval \\
Nechisar & 11 & $33(3)$ & $3(0.3)$ & 0 & 0 & 3 mongoose \\
Chebera-Churchura & 13 & $17(1.3)$ & $1(0.08)$ & 0 & 0 & 3 serval \\
Mago & 5 & $10(2)$ & 0 & 0 & 7 & 1 juvenile lion, 1 leop- \\
Kaffa Biosphere Reserve & 3 & $7(2.3)$ & $3(1)$ & 0 & 0 & ard and 3 elephants \\
Total & 46 & $145(3.1)$ & $23(0.5)$ & $2(0.04)$ & $7(0.2)$ & - \\
\hline
\end{tabular}


found along the road transects between the call-up stations. Large portions of Mago and Chebera-Churchura NPs were not accessible; we (Gidey Yirga, Fikirte Gebresenbet and Hans Bauer) confirmed lion presence there based on roars, footprints and confiscated skins.

\section{Semi-structured interviews}

Protected area staff fluent in the local language were trained to complete a four page semi-structured interview with both closed- and open-ended questions. A total of 809 household heads who were living in and nearby (less than $5 \mathrm{~km}$ from the borders) Awash $(n=208)$, Nechisar $(n=151)$, Chebera-Churchura $(n=150)$ and Mago $(n=300)$ were interviewed during September 2014 until April 2015 on four main issues: (1) conflict, (2) mitigation, (3) perception and (4) losses. Interviews in Kaffa Biosphere reserve used a different questionnaire and were not included here, they are reported elsewhere (Gebresenbet et al. 2017). For systematic selection, every third house was surveyed. We interviewed his wife or his elder son in the absence of the head of the household. To investigate perception of local people towards lion conservation, we measured perceptions by asking respondents to indicate how much they agreed or disagreed on a scale of 1-5 (1 strongly disagree, 5 strongly agree) with 14 statements. We collected data on livestock depredation, livestock loss factors, number of livestock lost, options for reducing livestock depredation, human attack and demographic data of each respondent. Respondents were clearly informed about our objectives and that responses were anonymised. There has not been any compensation for loss of livestock in Ethiopia to influence depredation losses. Data were analysed by JMP-5 statistical package.

\section{Anecdotal information}

For many years, we have been gathering anecdotal information on lion distribution. We used this information to present an educated guess about lion population status across Ethiopia. These guesses follow relatively simple rules: wherever lions are rare but present we assume a density of $<1$ lion per $100 \mathrm{~km}^{2}$ (i.e. low density, compared with the rest of Africa; Bauer and Van Der Merwe 2004), we assume a population size $<50$ lions for populations inferred to be very small (throughout Africa 50 is considered a small lion population; Bauer and Van Der Merwe 2004) and we assume a population size of $<25$ for populations inferred to be very small and heavily persecuted and/or fragmentedthe exact values are arbitrary but the point is to derive an order of magnitude.

\section{Results}

\section{Community characteristics}

A majority (91\%) of the respondents were male with a considerable number (48\%) within the age category of 21-31 years, followed by those who were $36-50$ years (47\%); 5\% was over 50 years (Table 2). Of a total of 809 respondents, 466 were illiterate (58\%) and 346 had a family size of 6-10 (43\%). Almost all respondents were agropastoralists with no other source of income. Most respondents ( $n=646,87 \%$ ) owned agricultural land less than 1 ha and more than half of respondents $(n=410,51 \%)$ had average annual income less than $\$ 243$ (local currency (ETB)

Table 2 Socio-demographic characteristic of 809 randomly selected respondents in Awash $(n=208)$, Nechisar $(n=151)$, CheberaChurchura $(n=150)$ and Mago $(n=300)$ national parks, Ethiopia

\begin{tabular}{|c|c|c|c|c|c|}
\hline & Awash & Nechisar & $\begin{array}{l}\text { Chebera- } \\
\text { Churchura }\end{array}$ & Mago & Total \\
\hline \multicolumn{6}{|l|}{ Gender } \\
\hline Male & 166 & 139 & 130 & 300 & 735 \\
\hline Female & 42 & 12 & 20 & 0 & 74 \\
\hline \multicolumn{6}{|l|}{ Age } \\
\hline $21-35$ & 122 & 93 & 70 & 104 & 389 \\
\hline $36-50$ & 77 & 50 & 73 & 181 & 381 \\
\hline $51-60$ & 7 & 8 & 7 & 15 & 37 \\
\hline$>60$ & 2 & 0 & 0 & 0 & 2 \\
\hline \multicolumn{6}{|l|}{ Education } \\
\hline Illiterate & 181 & 107 & 21 & 157 & 466 \\
\hline $1-4$ & 5 & 19 & 52 & 59 & 135 \\
\hline $5-8$ & 14 & 15 & 56 & 70 & 155 \\
\hline $9-10$ & 6 & 10 & 21 & 13 & 50 \\
\hline$>10$ & 2 & 0 & 0 & 1 & 3 \\
\hline \multicolumn{6}{|l|}{ Family size } \\
\hline $1-5$ & 128 & 63 & 66 & 131 & 388 \\
\hline $6-10$ & 60 & 55 & 73 & 158 & 346 \\
\hline$>10$ & 20 & 33 & 11 & 11 & 75 \\
\hline \multicolumn{6}{|l|}{ Average land holding } \\
\hline$<0.25$ ha & 5 & 76 & 37 & 5 & 123 \\
\hline $0.26-0.5$ ha & 14 & 11 & 37 & 63 & 125 \\
\hline $0.51-0.75$ ha & 105 & 35 & 21 & 47 & 208 \\
\hline $0.76-1$ ha & 12 & 9 & 26 & 143 & 190 \\
\hline$>1$ ha & 4 & 20 & 30 & 42 & 95 \\
\hline None & 68 & 0 & 0 & 0 & 68 \\
\hline \multicolumn{6}{|l|}{ Average income } \\
\hline$\leq 5000$ ETB & 11 & 63 & 66 & 270 & 410 \\
\hline 5001-10,000 ЕТВ & 46 & 32 & 65 & 30 & 173 \\
\hline $10,001-15,000$ ЕТВ & 101 & 23 & 2 & 0 & 126 \\
\hline$>15,000$ ETB & 50 & 33 & 17 & 0 & 100 \\
\hline
\end{tabular}




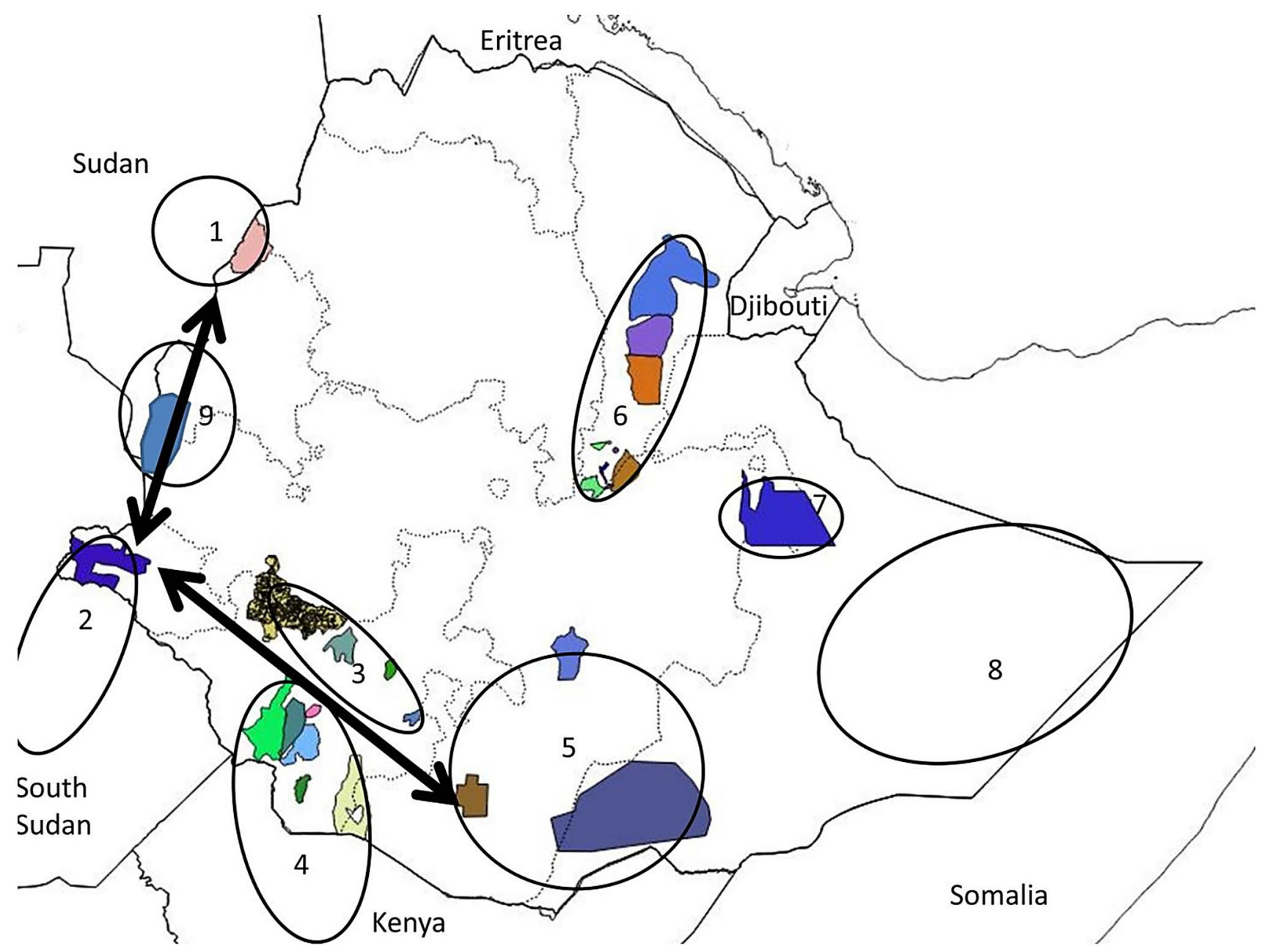

Fig. 2 Speculative lion distribution map. Protected areas are shown in colour; the circles present possible Lion Conservation Units, connectivity within and between circles unconfirmed $(1=$ Alatash-

translated to USD at the exchange rate of the time of the study) (\$1 was equivalent to ETB 20).

\section{Abundance of predators}

No lion responded to any of the call-ups, across all study sites. However, during fieldwork, we opportunistically observed six different lions. Two male and three female lions were encountered in Metahara sugar plantation that adjoins Awash. One juvenile lion and one leopard were encountered on our way to the second call-up in Mago. They probably responded to the first call-up by coming near to our car, but remained undetected. We did get a response from seven buffalo in Mago. In addition to our own opportunistic encounters, game scouts and other frequent visitors
Dinder, $\quad 2=$ Gambela-Boma, $\quad 3=$ Kafa-Chebera-Maze-Nechisar, 4=Omo-Mago-Turkana, 5= Geraile-Yabello-Bale, $6=$ Awash Valley, $7=$ Babile, $8=$ Ogaden-Somali, $9=$ Mao-Komo)

in each of the surveyed areas said they observe lions infrequently. There is recent $(<5$ year) proof of presence from all sites, but our conventional methods could not get enough detections to give a measure of abundance in any of them. We recorded 145 spotted hyaena $(3.2 \pm 29.2)$ and 23 jackal $(0.5 \pm 6.5)($ mean $\pm \mathrm{SD})$ responses at 25 and 13 of the 46 call-up stations, respectively (Table 1). The range of hyaenas and jackals responding per calling station were $0-25$ and $0-4$, respectively. Most $(n=115,83 \%)$ of the recorded hyaenas were found in calling stations located nearby $(<10 \mathrm{~km})$ human settlement areas. Two leopards responded to callups in Awash and they stayed around the car throughout the broadcast.

Our findings, combined with personal comments from various sources that visited other areas, give the revised 
distribution map and population guesstimates for Ethiopia shown in Fig. 2 and Table 3. Figure 2 shows known range; it is possible that the areas between polygons 1-5 are either permanent, occasional or connecting (dispersal) range, or a combination, because there are persistent but rare and unverified reports of lion sightings in those areas; it is unlikely that there is unknown lion range in the rest of the country (EWCA 2012).

\section{Perception towards lion conservation}

Overall, respondents held a mixed perception towards lions and lion conservation (Table 4). The majority did not see
Table 3 Estimates of lion abundance in Ethiopia in literature and as our informed guesses
Table 4 Results for items concerning lion management, knowledge and perception in Awash $(n=208)$, Nechisar ( $n=151)$, Chebera-Churchura $(n=150)$ and Mago $(n=300)$ national parks, Ethiopia

\begin{tabular}{lllll}
\hline & Current guess & $\begin{array}{l}\text { Gebresenbet et al. } \\
(2009)\end{array}$ & $\begin{array}{l}\text { Bauer and Van Der } \\
\text { Merwe }(2004)\end{array}$ & $\begin{array}{l}\text { Char- } \\
\text { donnet } \\
(2002)\end{array}$ \\
\hline $\begin{array}{lll}\text { Debus Valley } \\
\text { Alatash NP }\end{array}$ & 0 & & 60 \\
Gambela NP & $<50$ & $500^{\mathrm{a}}$ & 162 \\
Kafa Biosphere Reserve & $<100$ & & & \\
Chebera Churchura NP & $<50$ & & & \\
Maze NP & $<25$ & & $\mathrm{n} / \mathrm{a}$ & \\
Nechisar NP & $<25$ & 250 & 100 & 141 \\
Omo-Mago-Turkana & $<200$ & 100 & & 281 \\
Geraile NP & $<100$ & & 50 & 127 \\
Yabello NP & $<50$ & 50 & 250 & 423 \\
Bale Mountains NP & $<50$ & 50 & 300 & 350 \\
Awash Valley & $<100$ & & 150 & 480 \\
Babile Sanctuary & $<25$ & 100 & $\mathbf{1 0 0 0}$ & \\
Ogaden-Somali & $<200$ & & $\mathbf{2 1 4 4}$ \\
Mao-Komo & $<100$ & $\mathbf{1 0 5 0}$ & & \\
Total & $<\mathbf{1 1 0 0}$ & & & \\
\hline
\end{tabular}

${ }^{\mathrm{a}}$ This number covers a much larger area and includes Boma NP in Sudan

\begin{tabular}{llllll}
\hline Items & 1 & 2 & 3 & 4 & 5 \\
\hline Results for items concerning perception $n=809$ & & & & & \\
Lion is bad animal & 11 & 68 & 195 & $\mathbf{3 7 3}$ & 162 \\
The presence of lions is a sign of a healthy environment & 86 & $\mathbf{3 4 1}$ & 182 & 156 & 44 \\
Lion kills livestock & 51 & 24 & 38 & $\mathbf{4 8 3}$ & 213 \\
Lion have been known to attack and injure people & 88 & 99 & 213 & $\mathbf{2 4 6}$ & 163 \\
I would be afraid to go into the forest if there are lions & 43 & 34 & 171 & $\mathbf{4 0 4}$ & 157 \\
Lion is dangerous to humans & 6 & 39 & 323 & $\mathbf{3 2 8}$ & 113 \\
Lion should be protected & 20 & 262 & 143 & $\mathbf{2 8 7}$ & 97 \\
Results for items concerning lion management and knowledge $n=809$ & & & & & \\
There should be lions in the region & 16 & 33 & 80 & $\mathbf{4 2 5}$ & 255 \\
Lions should be present in my village & 216 & 156 & 142 & $\mathbf{2 5 3}$ & 42 \\
Lions should only live in restricted places & 2 & 47 & 71 & 343 & $\mathbf{3 4 6}$ \\
Farmers are responsible to protect their livestock from lion depredation & 23 & 130 & 82 & $\mathbf{3 4 5}$ & 229 \\
Money should be paid to farmers whose livestock is killed by lions & 15 & 20 & 139 & $\mathbf{4 1 7}$ & 218 \\
Killing of lions should be strictly regulated & 70 & 125 & $\mathbf{3 3 1}$ & 244 & 39 \\
Killing of lions should be allowed & 98 & $\mathbf{3 7 4}$ & 171 & 136 & 30 \\
It is necessary to give more people information about lions & $\mathbf{2 8}$ & $\mathbf{3 2}$ & $\mathbf{9}$ & 539 & $\mathbf{2 0 1}$ \\
\hline
\end{tabular}

Highest numbers in bold for ease of reference only

$1=$ strongly disagree, $2=$ disagree, $3=$ neutral, $4=$ agree and $5=$ strongly agree 
lion as a good animal that is part of a healthy environment (Table 4). A majority also agreed that lions kill livestock $(86 \%)$ and are dangerous to humans (55\%). However, while respondents viewed lions as dangerous carnivores and were thus negative about lions in practical terms, the majority of participants agreed that there should be lions in the region (84\%), preferentially in protected places (85\%). Most (35\%) respondents were against the killing of lions, but a small minority (16\%) strongly agreed that lions should be killed. Most (78\%) respondents were also in favour of compensation to farmers whose livestock was killed by lions. Most $(91.2 \%)$ respondents further agreed that it was necessary to give people more information about lions.

\section{Livestock loss factors}

The majority ( $n=762,94.2 \%)$ of respondents owned livestock and $38.3 \%$ reported losses to wild predators with an average of $5.5 \%$ of livestock per respondent over the past 5 years. Nearly $35 \%(n=282)$ and $5 \%(n=37)$ of the households surveyed reported losses of a total of $3.5 \%$ and $0.2 \%$ of their livestock to disease and theft, respectively, over the past 5 years (Fig. 3). A total of 1053 attack events were reported over the past 5 years, most by spotted hyaena $(47.7 \%$, $n=503)$, followed by leopard $(19.1 \%, n=201)$, then golden jackal $(17.3 \%, n=182)$, and lion $(15.9, n=167)$ (Table 5). While lions were responsible for relatively few cases overall, lions and spotted hyaenas were together and in almost
Table 5 Reported number of livestock depredation from a total of 809 randomly selected respondents in Awash $(n=736)$, Nechisar $(n=64)$, Chebera-Churchura $(n=97)$ and Mago $(n=156)$ national parks, Ethiopia over a period November 2011 to March 2015

\begin{tabular}{lrrrrr}
\hline Species & Stock & \multicolumn{3}{l}{ Depredation } \\
\cline { 3 - 6 } & & Lion & Hyena & Leopard & Jackal \\
\hline Cattle & 9105 & 145 & 161 & 5 & 0 \\
Goat & 5190 & 8 & 187 & 125 & 99 \\
Sheep & 3156 & 8 & 149 & 71 & 83 \\
Camel & 1541 & 4 & 4 & 0 & 0 \\
Donkey & 73 & 2 & 2 & 0 & 0 \\
Total & 19,065 & 167 & 503 & 201 & 182 \\
\hline
\end{tabular}

$*_{n}$ refers to reported number of livestock depredation in each national park

equal measure responsible for almost all depredation of cattle, the livestock category of most economic and cultural importance. Only one attack on humans was reported: in 2014 a 42-year-old man was injured by a lion in Mago. Compared with disease, the impact of depredation was higher for all livestock and almost double in the case of goats and sheep (Fig. 3). Guards (41.7\%, $n=454)$, enclosures (32.7\% $n=356)$ and $\operatorname{dogs}(25.7 \% n=280)$ were reported as the main livestock depredation mitigation tools, but their effectiveness was not assessed. About $16 \%(n=129)$ of the respondents had dogs to alert them to the presence of carnivores.

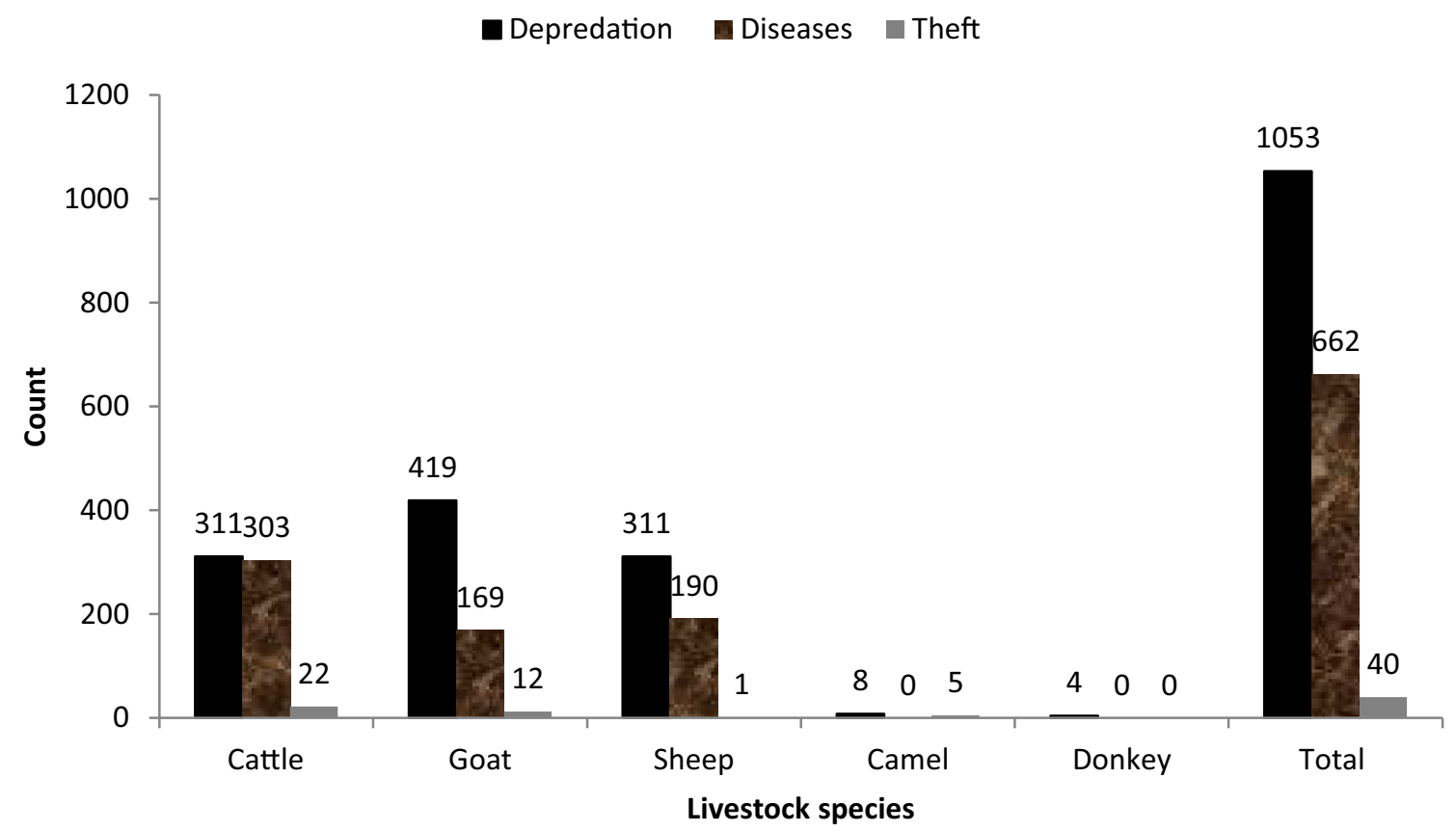

Fig. 3 Reported causes of livestock loss factors in Awash, Nechisar, Chebera-Churchura and Mago national parks, Ethiopia 


\section{Discussion}

\section{Lion abundance}

During our study a total of six different lions were opportunistically observed during field work, but no lion responded to any of the call-ups. We anticipated difficulties in the interpretation of our data due to shortcoming in our design; we know that the number and spatial distribution of our callups were insufficient for a representative sample. We also acknowledge that lions may avoid the few roads and that they may not respond in areas where they are persecuted and that densities may potentially have been higher deeper inside the PAs. The locations of our call-ups were not random and were not deep inside the PA's, but they were at the sites most likely to have lions within the constraints of the poor road network. We, therefore, take zero response to reflect a combination of low response rates and low densities. Each of these lion populations were hitherto considered to be important (Gebresenbet et al. 2009); their apparent decline in these areas raises concerns about the status of lions and raises doubt about the effectiveness of protected areas in Ethiopia.

More than ten lions were reportedly killed following livestock depredation in Mago, Awash and Nechisar in the past 2 years (Adego, Zerihun and Bayisa, pers. comm.). Yirga et al. (2014) reported livestock conflict as the main cause for the decline of large carnivore populations in Nechisar, with Guji herders persecuting large carnivores. Anthropogenic factors are driving the lions in Nechisar to extinction; reportedly any lion that ventures near livestock is pre-emptively shot (Yirga et al. 2014). Lions are being systematically killed for preying on livestock in Ethiopia. Other threats likely contributed, particularly prey depletion and habitat encroachment, but information is lacking on the degree to which different threats affect lions. Human-lion conflict is certainly an important contributor to declines in lion populations throughout Ethiopia, including those areas where they are formally protected (EWCA 2012).

On the basis of expert opinion, the lion population in Ethiopia has been estimated at 1000-2144 (Chardonnet 2002; Bauer and Van Der Merwe 2004), based on an incomplete dataset. Our knowledge of lion distribution in Ethiopia is still incomplete, but taking our new findings into account we provide a more coherent inventory of current guesstimates, pointing to a less favourable conservation status (Table 5). Figure 2 shows protected areas with lions; note that many protected areas in Ethiopia are still in the process of being gazetted, degazetted or redemarcated. Besides, their boundaries do not necessarily describe the limits of lion distribution; in some areas lions range far into community land, whereas in other areas communities have encroached the protected area. Figure 2 shows clusters of lion populations that were definitely historically connected, but we do not have information on current connectivity within or even between those clusters.

Our survey is significant for the conservation of lions in Ethiopia; anthropogenic factors are currently driving severe declines in the lion population. The actual range and numbers of lions in Ethiopia remain poorly known, but our findings are alarming.

\section{Perceptions towards lion conservation}

Our results suggest that pastoralists perceive lions as a risk factor to livestock and human safety. However, respondents do support well-managed regional lion conservation, preferentially in restricted protected areas. We note that a considerable number of people would, however, still tolerate lions 'in their village'. We thus observed heterogeneity among respondents with respect to the 'not in my backyard (NIMBY)' response, that is common in relation to dangerous wildlife (Chess 2000). Livestock depredation incidents are known to affect perceptions (Ericsson and Heberlein 2003; Naughton-Treves et al. 2003; Zimmermann et al. 2005; Baral and Henien 2007; Dar et al. 2009; Sogbohossou et al. 2011). Communities who experienced livestock depredation are less positive towards carnivores (Røskaft et al. 2007) and are more willing to kill them in retaliation and are against the increase of carnivore populations (Palmeira and Barrella 2007; Kissui 2008; Hazzah et al. 2009).

Our results suggest that improved management and protection of the lion populations is warranted, including improved protection of livestock and conflict mitigation. The Ethiopian Wildlife Conservation Authority should reduce conflicts and depredation to a tolerable level using available management measures and mitigation techniques (Frank et al. 2005; Bauer et al. 2010; Hazzah et al. 2014). Compensation for livestock losses could also be considered (Bauer et al. 2015a). Unfortunately, poaching, grazing and/or firewood/charcoal extraction is common (pers. obs.) in each of these NPs, partly due to limited EWCA capacity on the ground (Gebresenbet et al. 2013); over the past decade EWCA has not managed to get a single trespasser convicted. This impunity is part of the reason that NPs in Ethiopia are largely 'paper parks' (Gebresenbet et al. 2013). Serious law enforcement, possibly in combination with tourism development, could be part of the solution for conservation problems. Most of the local people are located inside and on the margins of the national parks and make extensive use of any easily accessible areas of forest to satisfy their needs such as fire wood, charcoal and construction material. There is no political will to change this; on the contrary, several government institutions are 
arguing for agricultural development of protected areas (Young 2012).

In all our study areas the relationship between the local people and park staff was mostly violent. During the study period, severe disputes over hunting erupted between local people and scouts in Awash and Mago national parks and people from the Mursi ethnic group killed a scout of Mago National Park in 2014. Similarly, in February 2003, people from the Banna ethnic group killed a warden of Mago National Park (Nishizaki 2005). In Ethiopia, effort to involve local people in wildlife management have been limited, whereas elsewhere community-based conservation has become one of the popular conservation strategies (Western and Wright 1994; Hulme and Murphree 1999).

\section{Livestock loss factors}

The impact of depredation was substantially higher than the impact of disease and theft for all livestock. Spotted hyaena and lion were the main predators for cattle, spotted hyaena and leopard for smaller livestock. Many researchers reported disease is responsible for livestock loss 3-6 times higher than livestock depredation (Gifford-Gonzalez 2000; Bauer 2003; Frank et al. 2005) and theft is one of the major factors causing livestock loss (Kynoch and Ulicki 2000; Dzimba and Matooane 2005; Nyahongo and Røskaft 2012) in Africa. In Africa theft is correlated with the stock that households own (Nyahongo and Røskaft 2012) and may cause significant livestock loss (Ogada et al. 2003). In comparison with other countries, the losses reported here are low and within the range of what is considered to be tolerable elsewhere (Borge 2003; Holmern et al. 2007; Kissui 2008).

\section{Conclusion and recommendations}

Our findings strongly suggest that lion numbers are low and may have substantially decreased in Awash, Nechisar, Chebera-Churchura, Mago and Kaffa and potentially across the country. Connectivity between the relatively small protected areas is another issue, also for other wide ranging large carnivores such as cheetah and wild dog. Ethiopia risks to lose its lions, which would carry not only ecological costs but also social and cultural losses. Urgent and focused conservation efforts are needed for the protection of these low density lion populations. Improved protected area management and awareness campaigns can help change people's perceptions towards wildlife and build on the still widespread cultural acceptance for some of the most charismatic species.
For future research, we suggest the use of distress calls from a set of local prey animals, the use of camera traps, spoor counts and other research techniques, and the monitoring of lion movements with collars in the focal areas. We also recommend gaining access to sectors of protected areas where such access is currently limited due to the absence of infrastructure.

Acknowledgements We are grateful to the International Foundation for Science (IFS) (D_5619_IFS), Rufford Small Grants for Nature Conservation and the German Nature Conservation Union (NABU) for financial and logistical assistance. Many thanks to the scouts and chief wardens of Awash, Nechisar, Chebera-Churchura, Mago and Kaffa.

Open Access This article is licensed under a Creative Commons Attribution 4.0 International License, which permits use, sharing, adaptation, distribution and reproduction in any medium or format, as long as you give appropriate credit to the original author(s) and the source, provide a link to the Creative Commons licence, and indicate if changes were made. The images or other third party material in this article are included in the article's Creative Commons licence, unless indicated otherwise in a credit line to the material. If material is not included in the article's Creative Commons licence and your intended use is not permitted by statutory regulation or exceeds the permitted use, you will need to obtain permission directly from the copyright holder. To view a copy of this licence, visit http://creativecommons.org/licenses/by/4.0/.

\section{References}

Alemayehu D (2011) challenges and opportunities for the establishment of community based ecotourism in the Awash National Park Area. M.sc thesis Addis Abeba University, Ethiopia

Baral N, Henien JT (2007) Resources use, conservation attitudes, management intervention and park people relations in the Western Terai landscape of Nepal. Environ Conserv 34:64-72

Bauer H (2003) Lion conservation in West and Central Africa. Ph.D. thesis Leiden University, The Netherlands

Bauer H, De Iongh HH (2005) Lion (Panthera leo) home ranges and livestock conflicts in Waza National Park, Cameroon. Afr J Ecol 43:208-214

Bauer H, Van Der Merwe S (2004) Inventory of free-ranging lions Panthera leo in Africa. Oryx 38:26-31

Bauer H, De Iongh HH, Sogbohossou E (2010) Assessment and mitigation of human-lion conflict in West and Central Africa. Mammalia 74:363-367

Bauer D, Schiess-Meier M, Mills DR, Gusset M (2014) Using spoor and prey counts to determine temporal and spatial variation in lion (Panthera leo) density. Can J Zool 92:97-104

Bauer H, Packer C, Funston PF, Henschel P, Nowell K (2015a). Panthera leo. The IUCN Red List of Threatened Species 2015. https:// doi.org/10.2305/IUCN.UK.2015-2.RLTS.T15951A50658092.en. Accessed 18 Nov 2015

Bauer H, Chapron G, Nowell K, Henschel P, Funston P, Hunter LTB, Macdonald DW, Packer C (2015b) Lion (Panthera leo) populations are declining rapidly across Africa, except in intensively managed areas. CrossMark 112:14894-14899

Bertola LD, Tensen L, Van Hooft P, White PA, DrscolL CA et al (2016) Autosomal and mt DNA markers affirm the distinctiveness of lions in West and Central Africa. PLoS ONE 11:e0149059. https:// doi.org/10.1371/journal.phone.0149059 
Borge A (2003) Essays on the economics of African wildlife utilization and man-agement. Norwegian University of Science and Technology, Norway

Chardonnet P (2002) Conservation of the African lion: contribution to a status survey. International Foundation for the Conservation of Wildlife, Paris, p 101

Chess C (2000) Evaluating environmental public participation: methodological questions. J Environ Plan Manage 43:769-784

Dar NI, Minhas RA, Zaman Q, Linkie M (2009) Predicting the patterns, perceptions and causes of human-carnivore conflict in and around Machiara National Park, Pakistan. Biol Conserv 142:2076-2082

Durant SM, Mitchell N, Groom R, Pettorelli N, Ipavec A, Jacobson AP et al (2017)The global decline of cheetah Acinonyx jubatus and what it means for conservation. Proc Natl Acad Sci USA 114(3):528-533

Dzimba J, Matooane M (2005) Stock theft and human security: a case study of Lesotho. www.iss.co.za/pubs/Monographs. Accessed 15 Nov 2015

Ebro A, Snyman HA, Smit GN (2004) Rangeland evaluation in the Middle Awash valley of Ethiopia: woody vegetation. In: Yimegnuhal A, Degefa T (eds) Farm animal biodiversity in Ethiopia. Status and prospects. Proceedings of the 11th annual conference of the Ethiopian society of animal production (ESAP) held in Addis Abeba, Ethiopia August 28-30, 2003. ESPA, Addis Abeba. pp 335-44

Ericsson G, Heberlein TA (2003) Attitudes of hunters, locals, and the general public in Sweden now that the wolves are back. Biol Conserv 111:149-159

EWCA (2012) National Action Plan for the Conservation of Lions in Ethiopia, Addis Ababa, Ethiopia

Frank LG, Woodroffe R, Ogada MO (2005) People and predators in Laikipia District, Kenya. In: Woodroffe R, Thirgood S, Rabinowitz A (eds) People and wildlife: conflict or coexistence? Cambridge University Press, Cambridge, pp 286-304

Gebresenbet F, Bauer H, Hunter L, Gebretensae K (2009) Proceedings of the National lion conservation workshop. EWCA, Addis Abeba, $47 \mathrm{pp}$

Gebresenbet F, Daniel W, Haile A, Bauer H (2013) Governance for effective and efficient conservation in Ethiopia. In: Raven PH, Sodhi NS, Gibson L (eds) Conservation biology: voices from the tropics. Wiley, Oxford. https://doi.org/10.1002/9781118679838.ch3

Gebresenbet F, Baraki B, Yirga G, Sillero-Zubiri C, Bauer H (2017) A culture of tolerance: coexisting with large carnivores in the Kafa Highlands, Ethiopia. Oryx 50:156-162

Gifford-Gonzalez D (2000) Animal disease challenges to the emergency of pastoral-ism in sub-Saharan Africa. Archael Rev 17:95-139

Gilfillan G, Vitale J, McNutt JW, McComb K (2016) Cross-modal individual recognition in wild African lions. Biol Lett 12:20160323. https://doi.org/10.1098/rsbl.2016.0323

Hazzah L, Mulder MB, Frank L (2009) Lions and warriors: social factors underlying declining African lion populations and the effect of incentive-based management in Kenya. Biol Conserv 142:2428-2437

Hazzah L, Dolrenry S, Naughton-Treves L, Edwards CT, Mwebi O, Kearney F, Frank L (2014) Efficacy of two lion conservation programs in Maasailand, Kenya. Conserv Biol 28:1441

Hillman JC (1993) A wildlife compendium for Ethiopia. Ethiopian Wildlife Conservation Organization (EWCO), Addis Abeba, p 786

Holmern T, Nyahongo J, Roskaft E (2007) Livestock loss caused by predators out-side the Serengeti National Park, Tanzania. Biol Conserv 135:518-526

Hulme D, Murphree M (1999) Communities, wildlife and the "new conservation" in Africa. J Int Dev 11:277-285
Kissui B (2008) Livestock predation by lions, leopards, spotted hyenas, and their vulnerability to retaliatory killing in the Maasai steppe, Tanzania. Anim Conserv 11:422-432

Kynoch G, Ulicki T (2000) Is it like the time of Lifaqana: the impact of stock theftand violence in southern Lesotho. J Contemp Afr Stud 18:179-206

NABU International Foundation for Nature (2012) Africa lions documented in montane rain forest. http://www.scoop.co.nz/stories. Accessed Feb 2016

Naughton-Treves L, Grossberg R, Treves A (2003) Paying for tolerance. Rural citizens'attitudes toward wolf depredation and compensation. Conserv Biol 17:1500-1511

Nishizaki N (2005) Differing local attitudes toward conservation Policy: a case study of Mago national park Ethiopia. Afr Study Monogr Suppl 29:31-40

Nyahongo JW, Røskaft E (2012) Assessment of livestock loss factors in the western Serengeti, Tanzania. Sustain Nat Resour Manage. https://doi.org/10.5772/36424

Ogada MO, Woodroffe R, Oguge NO, Frank LG (2003) Limiting depredation by African carnivores: the role of livestock husbandry. Conserv Biol 17:1521-1530

Ogutu JO, Dublin HT (1998) The response of lions and spotted hyaenas to sound playbacks as a technique for estimating population size. Afr J Ecol 36:83-95

Palmeira FBL, Barrella W (2007) Conflitos causados pela predaçao de rebanhos domésticos por grandes felines em comunidades quilombolas na Mata Atlântica. Biota Neotrop 7:119-128

Patterson PD (2007) On the nature and sigificance of viriability in lions (Panthera leo). Evol Biol 34:55-60

Ray J, Redford K, Steneck R, Berger J (eds) (2005) Large carnivores and the conservation of biodiversity. Island Press, Chicago

Riggio J, Jacobson A, Dollar L, Bauer H, Dickman A, Funston P, Henschel P, de Iongh H, Lichtenfeld L, Packer C, Pimm S (2013) The size of savannah Africa: a lion's view. Biodivers Conserv 22:17-35

Røskaft E, Händel B, Bjerke T, Kaltenborn BP (2007) Human attitudes towards large carnivores in Norway. Wildl Biol 13:172-185

Schuette P, Creel S, Christianson D (2013) Coexistence of African lions, livestock, and people in a landscape with variable human land use and seasonal movements. Biol Conserv 157:148-154

Shibru S (2016) Responses of vegetation, small mammals and Large herbivores to human induced pressures in the Savannah Plains of Nech Sar National Park, South Ethiopia Rift Valley. Ph.D. thesis evolutionary Ecology group, Antwerp University, Antwerp, Belgium

Shimelse S, Bekele T, Mengistu A (2010) Floristic diversity and structure of Nechisar National Park, Ethiopia. J Dry Lands 3:165-180

Sinclair A (2003) Mammal population regulation, keystone processes and ecosystem dynamics. Philos Trans R Soc Lond Ser b Biol Sci 358:1729-1740

Sogbohossou EA, De Iongh HH, Brice S, Snoo GR, Funstone P (2011) Human-carnivore conflicts around Pendjari Biosphere reserve, northern Benin. Oryx 6:1-10

Tilahun S, Edwards S, Tewolde B (1996) Important bird areas of Ethiopia: a first inventory. Ethiopian Wildlife and Natural History Society, Addis Ababa, $\mathrm{p} 30$

Timer G (2005) Diversity, abundance, distribution and habitat association of large mammals in the Chebera Churchura National Park, Ethiopia. M.Sc. thesis, Addis Ababa University, Addis Ababa (Unpublished), $127 \mathrm{p}$

Western D (2003) Conservation science in Africa and the role of international collaboration. Conserv Biol 17:11-19

Western D, Wright RM (1994) The background to community-based conservation. In: Western D, Wright RM (eds) Natural connections: perspectives in community-based conservation. Island Press, Washington, D.C., pp 1-14 
Yirga G, Gebresenbet F, Deckers J, Bauer H (2014) Status of lion (Panthera leo) and spotted hyena (Crocuta crocuta) in Nechisar National Park, Ethiopia. Momona Ethics J Sci 6:127-137

Young J (2012) Ethiopian protected areas a 'Snapshot'. A REFERENCE GUIDE FOR FUTURE STRATEGIC PLANNING AND PROJECT FUNDING at http://phe-ethiopia.org/admin/uploads/attachment1167. Accessed Feb 2016
Zimmermann A, Walpole MJ, Leader-Williams N (2005) Cattle ranchers 'attitudes to conflicts with jaguar Panthera onca in the Pantanal of Brazil. Oryx 39:406-412

Publisher's Note Springer Nature remains neutral with regard to jurisdictional claims in published maps and institutional affiliations. 